[Regular Paper]

\title{
Catalytic Wet Oxidation of Phenol Using Regeneration of $\mathrm{Pt} / \mathrm{Al}_{2} \mathrm{O}_{3}$
}

\author{
Dong-Keun LeE*, Byeong-Kweon Song, Su-Eon Jeong, Dul-Sun Kim, Tae-Han Kim, Young-Kyung LeE, \\ Ngoc Thuan Le, Mi-Jung Cho, and Sonia Devi HenAm
}

Dept. of Chemical and Biological Engineering, Environmental Biotechnology National Core Research Center (EBNCRC), Environmental and Regional Development Institute, BK21 Graduate Education Program for Environmental Core Technology, Gyeongsang National University, 900 Gajwa-dong, Jinju, Gyeongnam 660-701, KOREA

(Received October 14, 2009)

\begin{abstract}
Removal of phenol by wet air oxidation was conducted with $1 \mathrm{wt} \% \mathrm{Pt} / \mathrm{Al}_{2} \mathrm{O}_{3}$ catalyst in a batch reactor and in a continuous flow fluidized bed reactor with air lift tube operated at $423 \mathrm{~K}$ and $1.4 \mathrm{MPa}$. After $60 \mathrm{~min}$ in the batch reactor with initial phenol concentration of $1000 \mathrm{mg} / l$, almost complete conversion into $\mathrm{CO}_{2}$ and $\mathrm{H}_{2} \mathrm{O}$ was achieved. $\mathrm{Pt} / \mathrm{Al}_{2} \mathrm{O}_{3}$ catalyst deactivation was observed during the wet oxidation reaction. TEM, EDX, XPS and TPO analyses showed the deactivation was caused by formation and deposition of carbonaceous materials on the catalyst surface. TEM of the deactivated $\mathrm{Pt} / \mathrm{Al}_{2} \mathrm{O}_{3}$ showed formation of filamentous materials, which linked $\mathrm{Pt}$ particles, and some Pt particles were completely encapsulated by deposited material. XPS analysis showed that the carbonaceous materials on the catalyst consisted of four different morphologies $\left(\mathrm{C}_{1}, \mathrm{C}_{2}, \mathrm{C}_{3}, \mathrm{C}_{4}\right)$. As the wet oxidation proceeded, the $C_{1}$ peak increased gradually with reaction time, whereas the $C_{2}$ and $C_{3}$ peaks passed through maxima. At around the $\mathrm{C}_{2}$ and $\mathrm{C}_{3}$ peak maxima, the $\mathrm{C}_{4}$ peak began to appear and increased continuously up to $10 \mathrm{~h}$ reaction. This result indicates that at least two carbonaceous materials of $\mathrm{C}_{2}$ and $\mathrm{C}_{3}$ were transformed morphologically into $\mathrm{C}_{4}$ material. The broad profiles of $\mathrm{CO}_{2}$ formation from the TPO experiment implied that at least two types of carbon deposits were oxidized at different temperatures, one type on Pt particles, the other type on $\mathrm{Al}_{2} \mathrm{O}_{3}$. The carbonaceous deposit was formed on Pt particles and migrated continuously onto the support. The continuous flow fluidized bed reactor showed very stable wet oxidation performances in the presence of the air lift tube. The air lift tube was important in continuously regenerating the deactivated catalyst. The accumulated carbon deposits were reduced drastically by the action of the air lift tube.
\end{abstract}

\section{Keywords}

Carbonaceous material, Wet oxidation, Phenol, Platinum catalyst, Catalyst regeneration

\section{Introduction}

Many wastewater streams in the chemical process industry contain high concentrations of organic materials which are difficult to oxidize biologically. Phenol is one of the most common and important of such pollutants and is extremely toxic to the environment even at very low concentrations.

Wet air oxidation (WAO) is a very attractive and useful process for the treatment of effluents containing concentrations of organic pollutants that are too low for incineration and resistant to biological treatments, especially toxic effluents ${ }^{1 \sim 3}$. . WAO has been applied to removing total organic carbon (TOC) consisting of insoluble polymers ${ }^{4)}$, wastewaters ${ }^{5) \sim 8)}$, and certain organic compounds ${ }^{9), 10)}$. The efficient removal of pollutants via

This paper was presented at the 12th Japan-Korea Symposium on Catalysis, Akita, Japan, Oct. 14-16, 2009.

* To whom correspondence should be addressed.

* E-mail: d-klee@gsnu.ac.kr the WAO process requires very high temperature and pressure, typically in the range of 473-573 K and 7-15 MPa, respectively ${ }^{11)}$. However, such severe reaction conditions can lead to high installation costs, and practical applications of this process are limited. Therefore, catalytic wet air oxidation (CWAO) has been investigated to reduce the severity of the oxidation conditions. The use of catalysts improves the process by achieving high conversion at considerably lower temperature and pressure ${ }^{2), 12), 13)}$.

Many studies have investigated heterogeneously catalyzed WAO, but catalyst deactivation during WAO is mainly unknown. The present study investigated the CWAO of phenol in batch and continuous flow fluidized bed reactors at $423 \mathrm{~K}$ and $1.4 \mathrm{MPa}$ with $\mathrm{Pt} / \mathrm{Al}_{2} \mathrm{O}_{3}$ catalyst. Formation/migration of carbonaceous deposits on the catalyst surface was investigated, and a new method to regenerate the deactivated catalysts was tested in the fluidized bed reactor. 


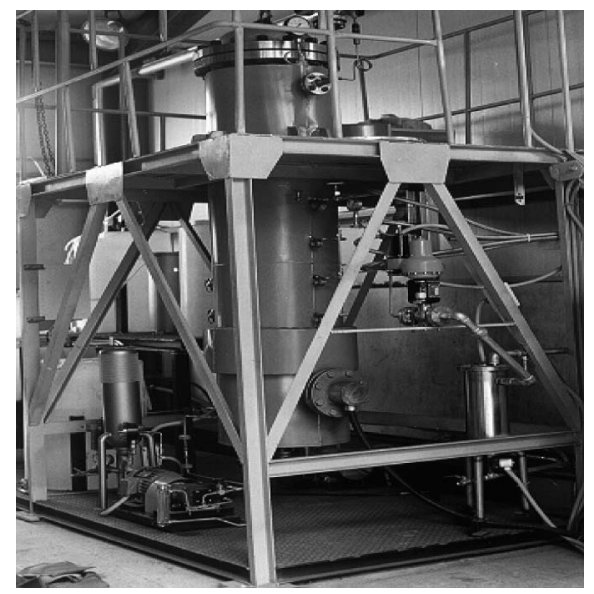

Fig. 1 Continuous Flow Fluidized Bed Reactor

\section{Experimental}

Platinum (II) acetylacetonate (Aldrich Co.) was used as the precursor of the $\mathrm{Pt} / \mathrm{Al}_{2} \mathrm{O}_{3}$ catalyst. $\quad \gamma-\mathrm{Al}_{2} \mathrm{O}_{3}$ (Strem Chemicals, Inc.) was used as the support for the $\mathrm{Pt} / \mathrm{Al}_{2} \mathrm{O}_{3}$ catalyst. All other chemicals were analytical reagent grade.

$1 \mathrm{wt} \% \mathrm{Pt} / \mathrm{Al}_{2} \mathrm{O}_{3}$ was prepared by the incipient wetness method. The platinum particles were located mainly at the exterior surface of the supports by pretreatment of the pores of $\gamma-\mathrm{Al}_{2} \mathrm{O}_{3}$ with $n$-hexane. The required amount of platinum (II) acetylacetonate solution was added to the supports dropwise. The prepared samples were then dried in vacuo at $323 \mathrm{~K}$. These preparation steps were repeated ten times to obtain $1 \mathrm{wt} \% \mathrm{Pt}$ loading. The prepared powder sample was then pressed into near-spherical particles with mean diameter of $80 \mu \mathrm{m}$ and mean apparent density of $1.03 \mathrm{~g} / \mathrm{cm}^{3}$. The samples were then calcined at $673 \mathrm{~K}$ for $4 \mathrm{~h}$ in a programmable furnace. The linear rate of heating up to $673 \mathrm{~K}$ was $0.5^{\circ} \mathrm{C} / \mathrm{min}$. The calcined samples were reduced under $\mathrm{H}_{2}$ flow at $573 \mathrm{~K}$ for $4 \mathrm{~h}$ and finally passivated at $298 \mathrm{~K}$ under $0.96 \% \mathrm{O}_{2} / \mathrm{He}$ gas mixture.

Oxidation of phenol solution was performed in a batch reactor and in a continuous flow fluidized bed reactor. An $1 l$ SS316 autoclave (Parr Instrument Co.) equipped with a teflon liner and a gas entrainment impeller with a variable-speed arrangement was used as the batch reactor. The continuous flow tubular fluidized bed reactor had $75 \mathrm{~cm}$ inside diameter and $2.25 \mathrm{~m}$ effective height as shown in Fig. 1. Generally $800 \mathrm{~g}$ of catalyst was used for the reaction. Phenol solution was fed into the reactor through a high pressure metering pump (Bran + Lubee) at the bottom of the reactor. Air was introduced into the reactor with a compressor. The pressure inside the reactor was maintained at 1.4 MPa with a back pressure regulator installed at the exit stream. A specially designed air lift tube $(1 \mathrm{~mm}$ inside diameter) was placed at the center of the reactor. Catalyst particles deactivated by accumulation of carbonaceous materials fell down to the bottom of the reactor. The upflowing air inside the air lift tube carried the deactivated catalyst particles up into the water-free space at the top of the reactor where the carbonaceous materials were oxidized with air. The regenerated catalyst particles were then returned to the fluidized bed. The volume of the water-free space was about $0.18 \mathrm{~m}^{3}$.

The dispersion of both platinum particles and carbonaceous materials in the $\mathrm{Pt} / \mathrm{Al}_{2} \mathrm{O}_{3}$ catalyst were observed by transmission electron microscopy (JEOL 200CX) at $160 \mathrm{keV}$. X-ray photoelectron spectroscopy (XPS) spectra of carbonaceous deposits were recorded by a VG ESCALAB 220 iXL spectrometer with a $\operatorname{MgK} \alpha$-source operating at $20 \mathrm{~mA}$ and $13 \mathrm{kV}$ at room temperature.

The carbonaceous materials deposited on the catalyst during the wet oxidation reaction were analyzed by the temperature-programmed oxidation (TPO) method using a mass spectrometer (HP 5970). In a typical TPO experiment, $0.2 \mathrm{~g}$ of the used catalyst was loaded in a quartz microreactor which was then installed in a furnace coupled to a temperature programmer. The catalyst was first exposed to helium flow $(100 \mathrm{ml} / \mathrm{min})$ and the temperature was raised at $10 \mathrm{~K} / \mathrm{min}$ to $393 \mathrm{~K}$ and kept at this temperature for $1 \mathrm{~h}$ before cooling to room temperature. Subsequently the catalyst was heated under a gas flow of $0.96 \%$ oxygen in helium at $10 \mathrm{~K} / \mathrm{min}$ to $973 \mathrm{~K}$. Analysis of the microreactor outlet gas was performed by mass spectrometry.

Reaction intermediates and phenol residue were identified and quantified with high performance liquid chromatography (HPLC) (Nihon Waters K.K.) using a Nova-Pak C18 column, and equipped with a tunable absorbance detector and MS spectrometer (HP 5970). Elution was performed at $1 \mathrm{ml} / \mathrm{min}$ flow rate of the mobile phase $\left(\mathrm{MeOH}: \mathrm{H}_{2} \mathrm{O}: \mathrm{H}_{3} \mathrm{PO}_{4}=40: 60: 0.5 \mathrm{vol} \%\right)$.

Total organic carbon (TOC) was measured with a Shimazu 5000A TOC analyzer based on combustion/ non-dispersive infrared (NDIR) gas analysis.

\section{Results and Discussion}

\section{1. Wet Oxidation of Phenol with $\mathrm{Pt} / \mathrm{Al}_{2} \mathrm{O}_{3}$}

To assess the extent of the uncatalyzed thermal oxidation of phenol and the effect of the support, WAO tests were performed without catalyst and with metalfree support using the initial phenol concentration of $1000 \mathrm{mg} / \mathrm{l}$. Uncatalyzed thermal oxidation did occur up to $5 \%$ in $3 \mathrm{~h}$, and the use of metal-free $\mathrm{Al}_{2} \mathrm{O}_{3}$ support resulted in somewhat lower oxidation efficiency than uncatalyzed oxidation (Fig. 2). Elevated temperature can lead to the formation of oxygen radicals $(\mathrm{O} \cdot)$, which can react with water to form hydroxyl radicals 


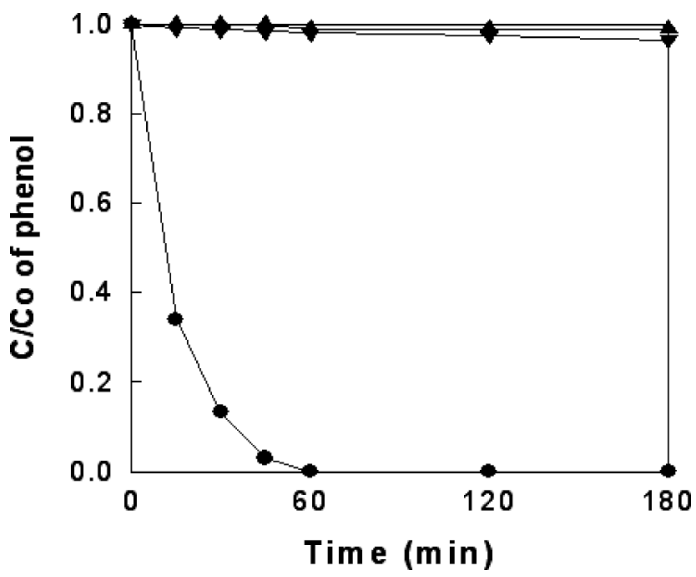

Fig. 2 Catalytic Wet Oxidation of Phenol at $423 \mathrm{~K}$ and $1.4 \mathrm{MPa}$ ( uncatalyzed reaction, $\nabla$ : reaction with metal-free $\mathrm{Al}_{2} \mathrm{O}_{3}$, reaction with $3 \mathrm{~g} 1 \mathrm{wt} \% \mathrm{Pt} / \mathrm{Al}_{2} \mathrm{O}_{3}$ catalyst)

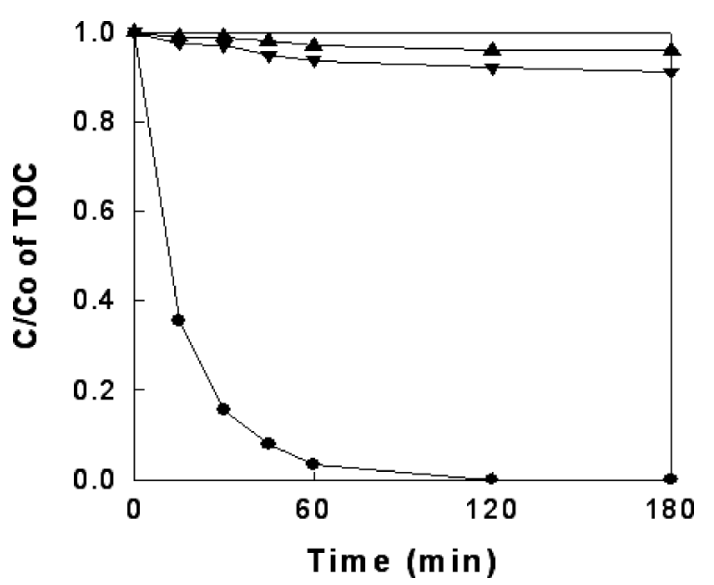

Fig. 3 Change in TOC Concentration during CWAO of Phenol at $423 \mathrm{~K}$ and $1.4 \mathrm{MPa}(\boldsymbol{\Delta}$ : uncatalyzed reaction, $\boldsymbol{\nabla}$ : reaction with metal-free $\mathrm{Al}_{2} \mathrm{O}_{3}$, $\mathrm{O}$ : reaction with $3 \mathrm{~g} 1 \mathrm{wt} \% \mathrm{Pt} / \mathrm{Al}_{2} \mathrm{O}_{3}$ catalyst)

$(\mathrm{HO} \cdot)^{-}$that may have oxidized phenol. However, the metal-free $\mathrm{Al}_{2} \mathrm{O}_{3}$ support acts to scavenge some of the hydroxyl radical formed. In contrast, use of $\mathrm{Pt} / \mathrm{Al}_{2} \mathrm{O}_{3}$ catalyst enhanced the oxidation appreciably, and almost complete conversion of phenol could be obtained in $60 \mathrm{~min}$. Analysis of the results of TOC showed that more than $95 \%$ of the initial phenol was removed after 60 min reaction with $\mathrm{Pt} / \mathrm{Al}_{2} \mathrm{O}_{3}$ catalyst (Fig. 3), and most phenol in Fig. 2 was completely oxidized into $\mathrm{CO}_{2}$ and water.

The effect of initial phenol concentration was investigated in the range $500-10,000 \mathrm{mg} / \mathrm{l}$ in the presence of $3.0 \mathrm{~g} \mathrm{Pt} / \mathrm{Al}_{2} \mathrm{O}_{3}$. The results in Fig. 4, showing the changes in phenol dimensionless concentration as a function of reaction time, indicate that higher initial phenol concentration resulted in lower conversion. Complete phenol conversion was obtained within $60 \mathrm{~min}$ with an initial phenol concentration of $1000 \mathrm{mg} / \mathrm{l}$

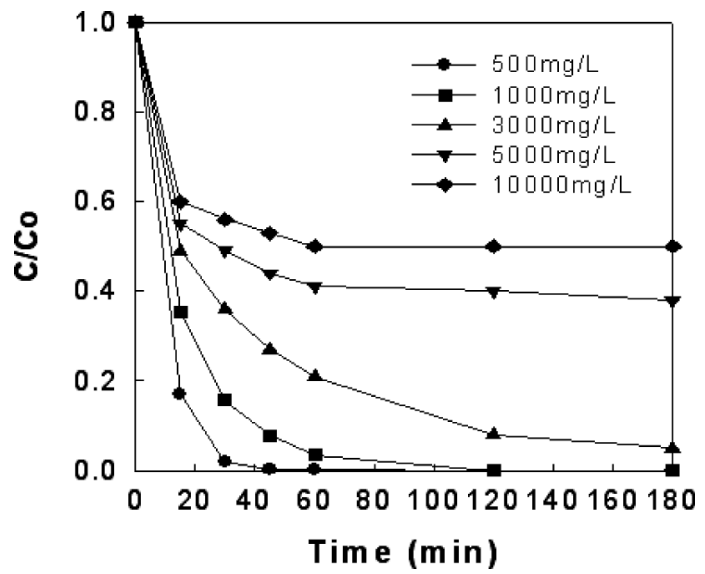

Fig. 4 Effect of Initial Phenol Concentration on Wet Oxidation of Phenol at $423 \mathrm{~K}$ and 1.4 $\mathrm{MPa}$ with $3 \mathrm{~g} \mathrm{Pt} / \mathrm{Al}_{2} \mathrm{O}_{3}$ Catalyst

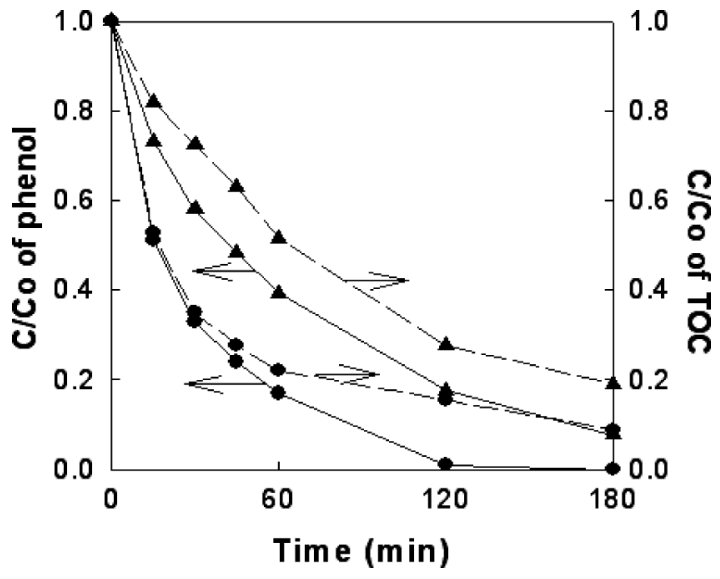

Fig. 5 Time Dependence of Relative Phenol and TOC Concentrations during $\mathrm{CWAO}$ of Phenol at $423 \mathrm{~K}$ and 1.4 $\mathrm{MPa}$ with $2 \mathrm{~g}$ Fresh $\mathrm{Pt} / \mathrm{Al}_{2} \mathrm{O}_{3}$ Catalyst ()$)$ and $2 \mathrm{~g}$ Used $\mathrm{Pt} / \mathrm{Al}_{2} \mathrm{O}_{3}$ Catalyst $(\boldsymbol{\Delta})$

or less, whereas only $50 \%$ conversion was achieved with the highest initial phenol concentration of $10,000 \mathrm{mg} / \mathrm{l}$. In addition, the conversion of phenol did not proceed and remained almost constant after $60 \mathrm{~min}$ reaction. This implies that catalyst deactivation might have occurred during the reaction which was highly dependent on the initial phenol concentration.

After CWAO of phenol was completed in $3 \mathrm{~h}$, the used catalyst sample was filtered and washed with distilled deionized water. The sample was then dried at $353 \mathrm{~K}$ for $24 \mathrm{~h}$, and the CWAO of phenol was repeated with initial phenol concentration of $1000 \mathrm{mg} / \mathrm{l}$ in the presence of the dried catalyst. As can be seen in Fig. 5, the efficiency of phenol removal and TOC removal could not successfully be restored. This deactivation of used catalyst might be due to either leaching of the active component $(\mathrm{Pt})$ of the catalyst during the reaction and/or accumulation of carbonaceous materials 


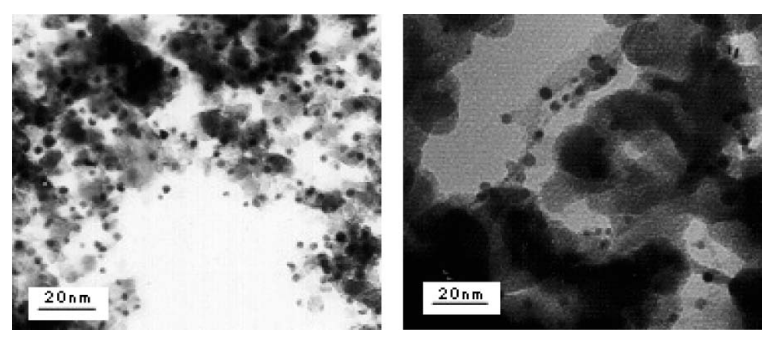

Fig. 6 TEM Micrographs of the Fresh $1 \mathrm{wt} \% \mathrm{Pt} / \mathrm{Al}_{2} \mathrm{O}_{3}$ (left) and $1 \mathrm{wt} \% \mathrm{Pt} / \mathrm{Al}_{2} \mathrm{O}_{3}$ (right) Catalysts after $3 \mathrm{~h}$ Reaction with Initial Phenol Concentration of $5000 \mathrm{mg} / \mathrm{l}$
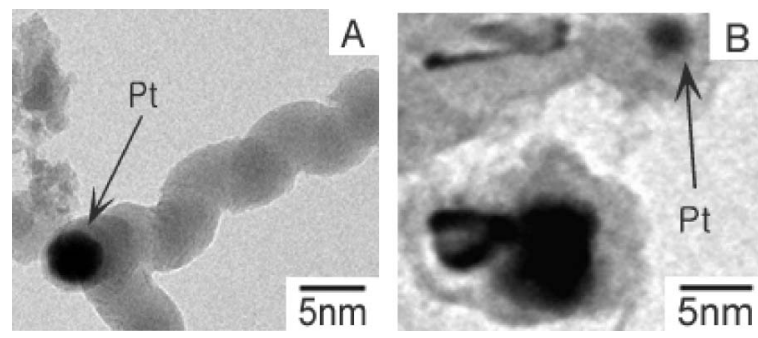

Fig. 7 Detailed TEM Micrographs of the $\mathrm{Pt} / \mathrm{Al}_{2} \mathrm{O}_{3}$ Catalysts after $3 \mathrm{~h}$ Reaction with Initial Phenol Concentration of $5000 \mathrm{mg} / \mathrm{l}$

deposited on the catalyst.

To investigate the stability of the $\mathrm{Pt} / \mathrm{Al}_{2} \mathrm{O}_{3}$ catalyst with respect to metal leaching, catalyst samples were taken after the reaction at various temperatures. The concentrations of the dissolved $\mathrm{Pt}$ and $\mathrm{Al}$ metals were analyzed using inductively coupled plasma (ICP), but no detectable amount of dissolved Pt and Al metals could be measured. Accordingly, no leaching occurred under the reaction conditions employed.

\section{2. Analysis of the Deactivated Catalysts}

Figure 6 shows transmission electron microscope (TEM) images of fresh and used $\mathrm{Pt} / \mathrm{Al}_{2} \mathrm{O}_{3}$ catalysts after wet oxidation of phenol for $3 \mathrm{~h}$ with initial concentration $5000 \mathrm{mg} / l$. The fresh $\mathrm{Pt} / \mathrm{Al}_{2} \mathrm{O}_{3}$ catalyst is clean and free of any deposited materials, whereas the used $\mathrm{Pt} / \mathrm{Al}_{2} \mathrm{O}_{3}$ catalyst incorporates huge amounts of deposited material, especially on the surface. Detailed observation of the deactivated $\mathrm{Pt} / \mathrm{Al}_{2} \mathrm{O}_{3}$ catalyst clearly shows the formation of filamentous materials linking the $\mathrm{Pt}$ particles (Fig. 7A). In addition, some of the Pt particles are completely encapsulated by deposited material (Fig. 7B).

Energy dispersive X-ray fluorescence spectrometer (EDX) analysis of the used catalysts demonstrated that the dominant component of the deposited material was carbon. XPS spectra of the used catalysts after reaction with different initial phenol concentrations and reaction times indicated the emergence of a strong $\mathrm{C} 1 \mathrm{~s}$ peak, confirming the presence of carbonaceous deposits on the catalyst surface. Figure 8 shows representative XPS C1s spectra of the $\mathrm{Pt} / \mathrm{Al}_{2} \mathrm{O}_{3}$ catalyst after reaction

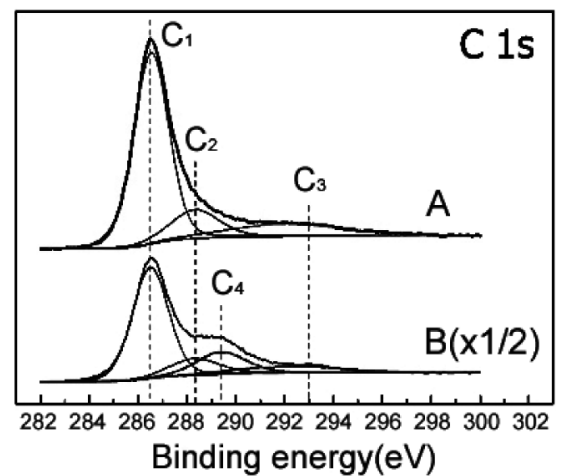

Fig. 8 XPS Cls Spectra of $\mathrm{Pt} / \mathrm{Al}_{2} \mathrm{O}_{3}$ after Reaction for $1 \mathrm{~h} \mathrm{(A)}$ and $4 \mathrm{~h}$ (B) with Initial Phenol Concentration of $1000 \mathrm{mg} / \mathrm{l}$

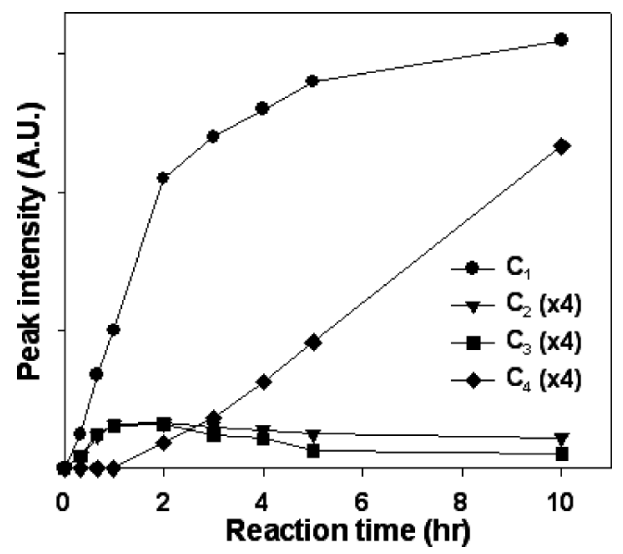

Fig. 9 Changes in the XPS Peak Intensities with Reaction Time for $\mathrm{Pt} / \mathrm{Al}_{2} \mathrm{O}_{3}$ Catalyst

for $1 \mathrm{~h}(\mathrm{~A})$ and $4 \mathrm{~h}(\mathrm{~B})$ with initial phenol concentration of $1000 \mathrm{mg} / \mathrm{l}$. The maximum intensity of the $\mathrm{C} 1 \mathrm{~s}$ peak appears at binding energy of $286.3 \mathrm{eV}$. The peak intensity of $\mathrm{C} 1 \mathrm{~s}$ in $\mathrm{Pt} / \mathrm{Al}_{2} \mathrm{O}_{3}$ catalysts increased with higher initial phenol concentration, but the shape and binding energy of the peak were almost unchanged. Deconvolution of the XPS spectrum obtained after $1 \mathrm{~h}$ reaction $(\mathrm{A})$ showed that the $\mathrm{C} 1 \mathrm{~s}$ peak consisted of $\mathrm{C} 1$ (286.4 eV), $\mathrm{C}_{2}(288.2 \mathrm{eV})$ and $\mathrm{C}_{3}(292.9 \mathrm{eV})$ peaks. $\mathrm{A}$ new peak of $\mathrm{C}_{4}$ appeared at the binding energy $289.3 \mathrm{eV}$ after reaction for another $3 \mathrm{~h}$ (B).

Figure 9 plots the changes in the intensities of four representative peaks of $\mathrm{C} 1 \mathrm{~s}$ spectra with reaction time. The $\mathrm{C}_{1}$ peak gradually increased with reaction time, whereas the $\mathrm{C}_{2}$ and $\mathrm{C}_{3}$ peaks passed through maxima. The $\mathrm{C}_{4}$ peak began to appear at around the time of the $\mathrm{C}_{2}$ and $\mathrm{C}_{3}$ maxima, and increased continuously up to $10 \mathrm{~h}$ reaction time. This result indicates that at least two carbonaceous materials, $\mathrm{C}_{2}$ and $\mathrm{C}_{3}$, transformed morphologically into $\mathrm{C}_{4}$.

Carbonaceous deposits on the catalysts were analyzed with TPO. Burn-off profiles of carbonaceous deposits on the catalysts after reaction for $3 \mathrm{~h}$ with ini- 

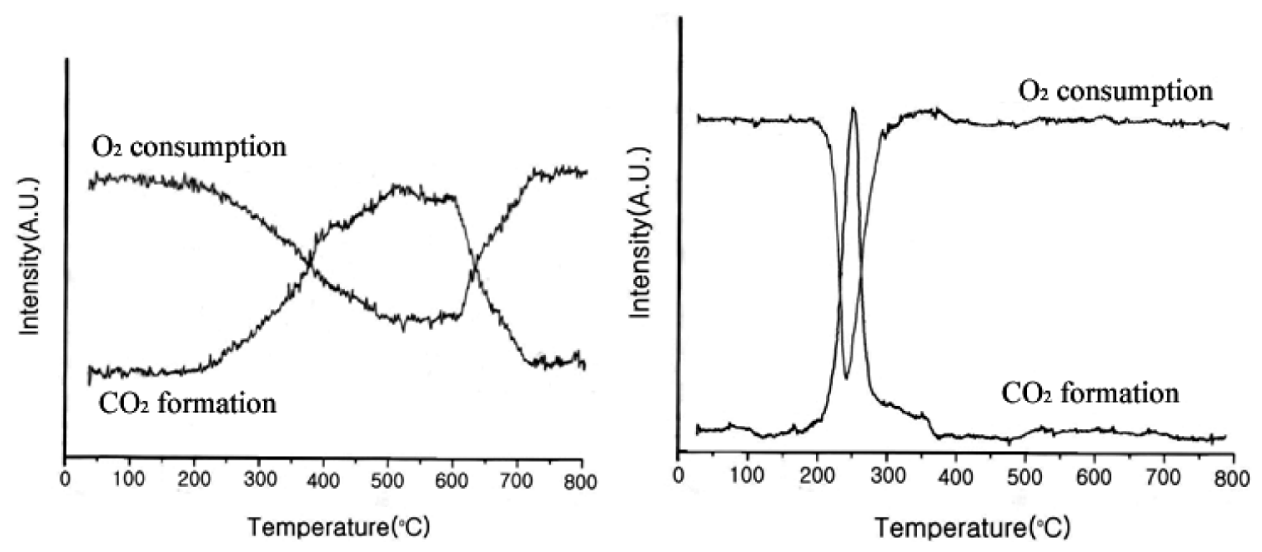

Fig. 10 Profiles of $\mathrm{O}_{2}$ Consumption and $\mathrm{CO}_{2}$ Formation during TPO Experiments with $\mathrm{Pt} / \mathrm{Al}_{2} \mathrm{O}_{3}$ (left) and Pt Powder (right) after Reaction for $3 \mathrm{~h}$ with Initial Phenol Concentration of $5000 \mathrm{mg} / \mathrm{l}$

tial phenol concentration of $5000 \mathrm{mg} / \mathrm{l}$ are shown in Fig. 10. Formation of $\mathrm{CO}_{2}$ over a broad temperature ranges from 250 to $700^{\circ} \mathrm{C}$ over $\mathrm{Pt} / \mathrm{Al}_{2} \mathrm{O}_{3}$ catalyst in accordance with the consumption of oxygen. The carbonaceous deposit on $\mathrm{Pt}$ powder was burned off over narrow temperature range around $250^{\circ} \mathrm{C}$ and was completely removed below $300^{\circ} \mathrm{C}$. Therefore, carbonaceous materials must have been deposited on the catalyst during the wet oxidation of phenol, and concurrent catalyst deactivation was caused by the deposition of carbonaceous materials.

Assuming that the carbonaceous deposits on $\mathrm{Pt} / \mathrm{Al}_{2} \mathrm{O}_{3}$ and $\mathrm{Al}_{2} \mathrm{O}_{3}$ support have the same chemical composition and configuration, carbonaceous deposits on both catalysts are expected to be oxidized at the same narrow temperature range during the TPO experiment. However, the carbonaceous deposits on $\mathrm{Pt} / \mathrm{Al}_{2} \mathrm{O}_{3}$ were less reactive toward oxygen (or more difficult to oxidize) than those on $\mathrm{Al}_{2} \mathrm{O}_{3}$ support. Carbon deposits on alumina support are reported to be oxidized at temperatures higher than $440^{\circ} \mathrm{C}{ }^{14)}$. The presence of Pt metal could catalyze the oxidation of carbon deposits, and Ptcatalyzed oxidation of carbon is known to occur generally at temperatures around $280^{\circ} \mathrm{C}{ }^{15), 16)}$.

The broad profile of $\mathrm{CO}_{2}$ formation over $\mathrm{Pt} / \mathrm{Al}_{2} \mathrm{O}_{3}$ implies at least two types of carbon deposits oxidizing at different temperatures. One type of deposit on the surface of $\mathrm{Pt}$ particles is oxidized at around $250^{\circ} \mathrm{C}$, whereas the other type on $\mathrm{Al}_{2} \mathrm{O}_{3}$ will oxidize at much higher temperatures. The presence of filamentous carbons linking Pt particles on $\mathrm{Al}_{2} \mathrm{O}_{3}$ was confirmed by TEM as shown in Figs. 6 and 7.

\section{3. Migration of Carbonaceous Deposits}

Since the conversion of phenol on Pt-free $\mathrm{Al}_{2} \mathrm{O}_{3}$ support was almost negligible as shown in Fig. 2, both wet oxidation of phenol and initial formation of carbonaceous deposits occur predominantly on the surface of $\mathrm{Pt}$ particles. These carbon deposits will then migrate onto the surface of $\mathrm{Al}_{2} \mathrm{O}_{3}$ in the vicinity of the Pt parti-

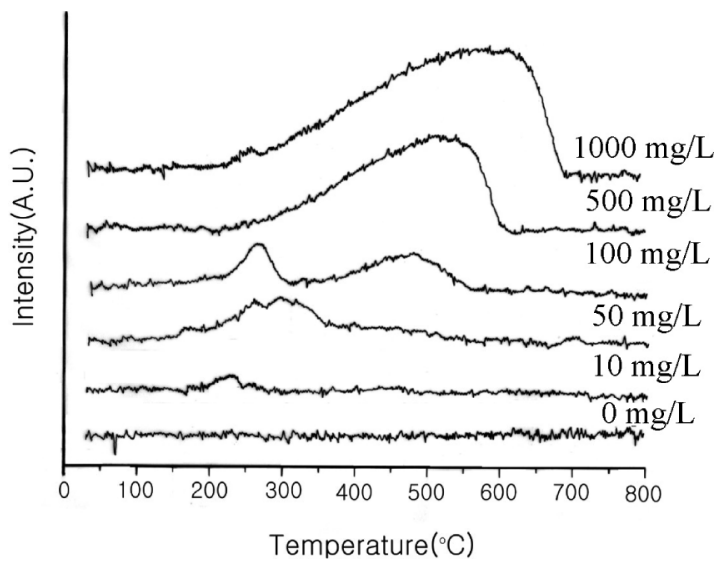

Fig. 11 Effect of Initial Phenol Concentration on $\mathrm{CO}_{2}$ Formation Profiles of $\mathrm{Pt} / \mathrm{Al}_{2} \mathrm{O}_{3}$

cles. To investigate the migration of carbonaceous deposits, TPO experiments used oxidation of phenol for $3 \mathrm{~h}$ over $\mathrm{Pt} / \mathrm{Al}_{2} \mathrm{O}_{3}$ with initial phenol concentrations of $10,50,100,500$ and $1000 \mathrm{mg} / l$. The profiles of $\mathrm{CO}_{2}$ formation for $\mathrm{Pt} / \mathrm{Al}_{2} \mathrm{O}_{3}$ are shown in Fig. 11. At initial phenol concentration of $50 \mathrm{mg} / \mathrm{l}$ or less, most $\mathrm{CO}_{2}$ was produced at temperatures below $300^{\circ} \mathrm{C}$. These $\mathrm{CO}_{2}$ peaks are nearly the same as the $\mathrm{CO}_{2}$ peak from $\mathrm{Pt}$ powder (Fig. 10), indicating that carbonaceous deposits are primarily formed on the surface of Pt particles. At initial phenol concentration of $100 \mathrm{mg} / l$, new higher temperature peaks occurred which increased with higher initial phenol concentration. The changes in the profiles of $\mathrm{CO}_{2}$ formation with initial phenol concentration indicate that the carbonaceous deposits formed on $\mathrm{Pt}$ particles migrated onto the surface of $\mathrm{Al}_{2} \mathrm{O}_{3}$. Furthermore, careful examination of the TEM micrographs of $\mathrm{Pt} / \mathrm{Al}_{2} \mathrm{O}_{3}$ (Figs. 6 and 7) indicates that the carbonaceous materials on the supports acted as bridges connecting the Pt particles. 


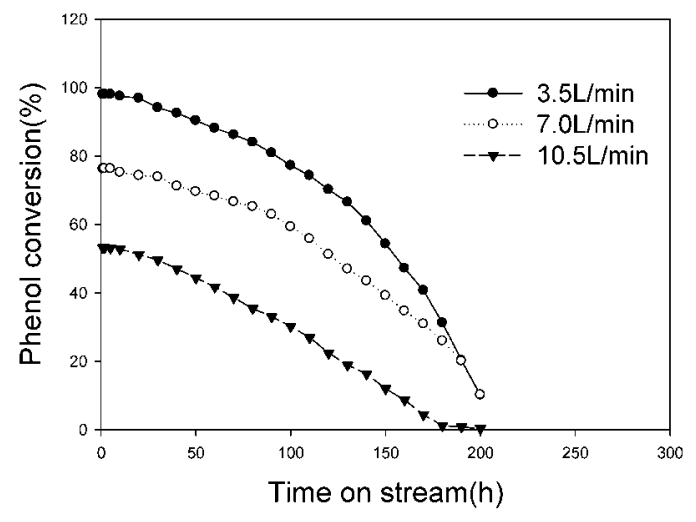

Fig. 12 Phenol Conversions in the Continuous Flow Fluidized Bed Reactor without Air Lift Tube at Different Phenol Solution Flow Rates

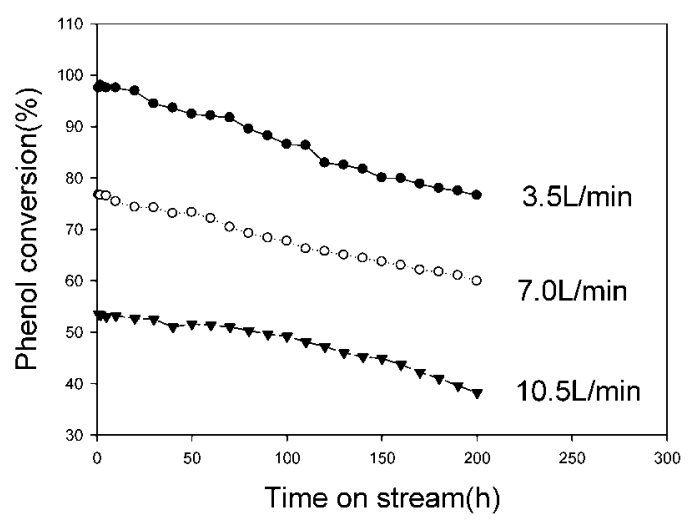

Fig. 13 Phenol Conversions in the Continuous Flow Reactor with Air Lift Tube at Different Phenol Solution Flow Rates

\section{4. Continuous Flow Wet Oxidation}

Figure 12 shows the performances of the fluidized bed reactor without the air lift tube. More than $97 \%$ phenol can be removed up to $10 \mathrm{~h}$ continuous operation under flow rate of $3.5 \mathrm{l} / \mathrm{min}$. However, conversion then decreased continuously due to catalyst deactivation by carbon deposits. Similar results were obtained at higher flow rates of $7.0 \mathrm{l} / \mathrm{min}$ and $10.5 \mathrm{l} / \mathrm{min}$. In the presence of the air lift tube (Fig. 13), the conversions decreased slightly, which indicates that the air lift tube is important in the oxidation of the carbon deposits, so regenerating the catalysts.

The TPO results in Fig. 14 demonstrate that the air tube must operate somewhat successfully to regenerate the deactivated catalysts. In the absence of the air lift tube, two main $\mathrm{CO}_{2}$ peaks were produced at around $170^{\circ} \mathrm{C}$ and $300^{\circ} \mathrm{C}$ at the flow rate of $3.5 \mathrm{l} / \mathrm{min}$. With increasing flow rate, the low temperature peak intensity decreased due to lower phenol conversion at higher flow rates. In the reaction with just $\mathrm{Al}_{2} \mathrm{O}_{3}$, one representative $\mathrm{CO}_{2}$ peak appeared at $140^{\circ} \mathrm{C}$. In the presence of the air lift tube, $\mathrm{CO}_{2}$ production decreased drastically. In the case of only $\mathrm{Al}_{2} \mathrm{O}_{3}$, no detectable

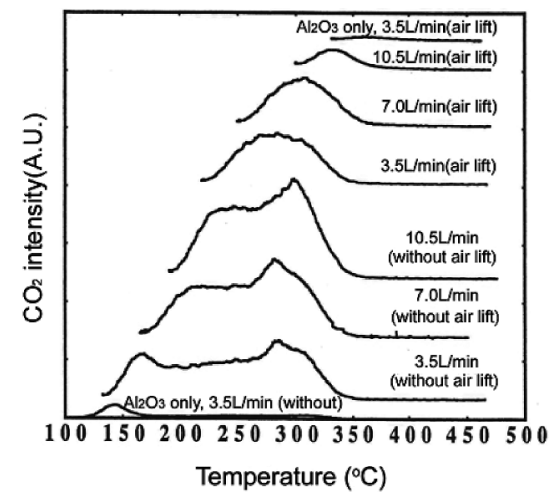

Fig. 14 TPO Profiles of the Pt-free $\mathrm{Al}_{2} \mathrm{O}_{3}$ and $1 \mathrm{wt} \% \mathrm{Pt} / \mathrm{Al}_{2} \mathrm{O}_{3}$ Catalysts after Use in the Continuous Flow Fluidized Bed Reactor

amounts of $\mathrm{CO}_{2}$ were observed.

\section{Conclusions}

Catalytic wet oxidation of phenol was carried out with $1 \mathrm{wt} \% \mathrm{Pt} / \mathrm{Al}_{2} \mathrm{O}_{3}$ in a batch reactor and in a continuous flow fluidized bed reactor with air lift tube operated at $423 \mathrm{~K}$ and 1.4 MPa.

Catalyst deactivation was observed especially on $\mathrm{Pt} /$ $\mathrm{Al}_{2} \mathrm{O}_{3}$ during the wet oxidation reaction. TEM, EDX, XPS and TPO analyses suggested the deactivation was caused by the formation and deposition of carbonaceous materials on the catalyst surface. The profiles of $\mathrm{CO}_{2}$ formation in TPO experiments on $\mathrm{Pt} / \mathrm{Al}_{2} \mathrm{O}_{3}$ and $\mathrm{Al}_{2} \mathrm{O}_{3}$ free $\mathrm{Pt}$ metal were different.

Carbonaceous deposits were located on the surface of Pt particles as well as supports. The deposits on Pt particles rather than the deposits on the support were much more reactive to oxygen. The different reactivities of these deposits to oxygen resulted in the appearance of broad $\mathrm{CO}_{2}$ formation profiles in the temperature range $250-700^{\circ} \mathrm{C}$ for $\mathrm{Pt} / \mathrm{Al}_{2} \mathrm{O}_{3}$.

Sequential $\mathrm{CO}_{2}$ formation profiles showed that the carbonaceous deposits were primarily formed on the surface of the Pt particles and then migrated continuously onto the surface of $\mathrm{Al}_{2} \mathrm{O}_{3}$ in the vicinity of the $\mathrm{Pt}$ particles.

The continuous flow fluidized bed reactor showed very stable wet oxidation performances in the presence of the air lift tube. The accumulated carbon deposits were reduced drastically due to the action of the air lift tube.

\section{Acknowledgments}

This work was supported by a grant from the KOSEF/MOST to the Environmental Biotechnology National Core Research Center (grant \#: R15-2003012-02002-0). 


\section{References}

1) Levec, J., Appl. Catal., 63, L1 (1990).

2) Levec, J., Pintar, A., Catal. Today, 24, 51 (1995).

3) Randall, T. L., Knopp, P. V. J., Water Pollut. Control Fed., 52, 2117 (1980).

4) Mantzavinos, D., Hellenbrand, R., Livingston, A. G., Metcalfe, I. S., Appl. Catal. B: Environmental, 11, 99 (1996).

5) Chang, C. J., Lin, J. C., J. Chem. Tech. Biotechnol., 57, 355 (1993).

6) Pintar, A., Levec, J., Chem. Eng. Sci., 47, 2395 (1992).

7) Dietrich, M. J., Randall, T. L., Channey, D., J. Environ. Progress, 4, 171 (1985).

8) Lin, S. H., Ho, S., Appl. Catal. B: Environmental, 9, 133
(1996).

9) Atwater, J. E., Akse, J. R., Mckinnis, J. A., Thompson, J. O., Appl. Catal. B: Environmental, 11, L11 (1996).

10) Hogan, T., Simpson, R., Kin, M., Sen, A., Catal. Lett., 40, 95 (1996).

11) Zimmerman, E., J. Chem. Eng., 56, 117 (1958).

12) Luck, F., Catal. Today, 27, 195 (1996).

13) Lee, D.-K., Kim, D.-S., Catal. Today, 63, 249 (2001).

14) Augustime, S. M., Alameddin, G. N., Sachtler, W. M. H., J. Catal., 115, 217 (1989).

15) Hamoudi, S., Larachi, F., Sayari, A., J. Catal., 177, 247 (1998).

16) Pieck, C. L., Verderone, R. J., Jablonski, E. L., Parera, J. M., Appl. Catal., 55, 1 (1989).

要 旨

\section{再生可能な $\mathrm{Pt} / \mathrm{Al}_{2} \mathrm{O}_{3}$ 触媒を用いるフェノールの湿式酸化反応}

Dong-Keun LeE, Byeong-Kweon Song, Su-Eon Jeong, Dul-Sun KIM, Tae-Han KIM, Young-Kyung LeE,

Ngoc Thuan Le, Mi-Jung CHO, and Sonia Devi Henam

Dept. of Chemical and Biological Engineering, Environmental Biotechnology National Core Research Center (EBNCRC), Environmental and Regional Development Institute, BK21 Graduate Education Program for Environmental Core Technology, Gyeongsang National University, 900 Gajwa-dong, Jinju, Gyeongnam 660-701, KOREA

$1 \mathrm{wt} \% \mathrm{Pt} / \mathrm{Al}_{2} \mathrm{O}_{3}$ 触媒を用い湿式酸化によるフェノール除去を 行った。バッチ式反応器による処理では初期濃度 $1000 \mathrm{mg} / \mathrm{l}$ の フェノールを 60 分でほとんど全て二酸化炭素と水に酸化する ことができたが, $\mathrm{Pt} / \mathrm{Al}_{2} \mathrm{O}_{3}$ 触媒の劣化が起こった。種々のキャ ラクタリゼーションにより, 活性の劣化は触媒表面への炭素質 の堆積が原因であることを示した。TEM 観察では, 劣化した $\mathrm{Pt} / \mathrm{Al}_{2} \mathrm{O}_{3}$ 触媒にはフィラメント状の堆積物が白金粒子と結合し ている像や，白金粒子が堆積物に完全に埋まっている像が示さ れた。XPS 分析では炭素質堆積物として, 湿式酸化の進行に 伴い増大するもの $\left(\mathrm{C}_{1}\right)$, 極大をもつもの $\left(\mathrm{C}_{2}, \mathrm{C}_{3}\right)$, そして $\mathrm{C}_{2}$
と $\mathrm{C}_{3}$ が極大值を示す時から観測されその後増加するもの $\left(\mathrm{C}_{4}\right)$ などの 4 種類が存在すること, また反応中に $\mathrm{C}_{2}$ と $\mathrm{C}_{3}$ の炭素質 堆積物が $\mathrm{C}_{4}$ へと構造変化することが示された。TEM, EDX, XPS およびTPO 分析から, 炭素質堆積は白金上に存在するも のとアルミナ上の二種類存在し, 白金粒子上の炭素質堆積物は 担体上に移動することが示された。 $423 \mathrm{~K}, 1.4 \mathrm{MPa}$ で駆動す るエアーリフト管を備えた連続流動床反応器による湿式酸化反 応実験から, 空気処理により $\mathrm{Pt} / \mathrm{Al}_{2} \mathrm{O}_{3}$ 触媒上の炭素質堆積物が 除かれ，活性が安定することが示された。 